\title{
Carta aberta aos/às trabalhadores/as em educação e à sociedade sobre os retrocessos na agenda social do país
}

s primeiras medidas do governo federal sob a chefia do presidente Jair Messias
Bolsonaro, eleito em outubro de 2018 na sequência do golpe político-jurídico-
midiático instituído no País em 2016, preocupam a todos/as que militam em diferentes áreas sociais e que confiam ao Estado o compromisso de instituir e regular políticas públicas para promover o desenvolvimento com inclusão e igualdade social e com sustentabilidade ambiental.

A educação e o trabalho, assim como outros direitos fundamentais previstos na Carta Magna de 1988, formam a base de qualquer projeto de Nação soberana, próspera, igualitária e fraterna. Porém, muitas das medidas anunciadas pelo novo governo se mostram anacrônicas ao remontarem privilégios históricos de setores abastados, a exemplo da extinção do Ministério do Trabalho e Emprego, com o claro propósito de avançar na desregulamentação dos direitos trabalhistas, em benefício dos patrões, podendo a situação ficar ainda mais caótica caso se confirme a intenção governamental de propor o fim da Justiça do Trabalho.

Tão grave quanto o fim das instituições de proteção ao trabalho, foi a decisão do governo de remeter para o Ministério da Justiça e Segurança Pública os assuntos relacionados ao movimento sindical, regredindo em mais de século a prática estatal que submetia a organização dos trabalhadores brasileiros à força coercitiva do Estado. Outra medida descabida e extemporânea se refere à perseguição estatal a determinados grupos sociais (indígenas, quilombolas, mulheres, juventude, camponeses, LGBT), que tiveram extintos importantes órgãos de representação e mecanismos estatais de proteção humanitária e de subsistência. O meio ambiente e a agricultura familiar sofrerão graves consequências com o (des)controle de inúmeras políticas em mãos do agronegócio. Caberá ao Ministério da Agricultura, Pecuária e Abastecimento a edição e o controle de regras relativas a defensivos agrícolas, demarcação de terras indígenas e quilombolas, reforma agrária, fomento ao pequeno agricultor etc.

A junção dos Ministérios da Economia, do Planejamento, da Previdência e da Indústria e Comércio, sob a tutela de um dos maiores capitalistas nacionais (o ministro Paulo Guedes é sócio majoritário do grupo financeiro BR Investimentos e do Ibemec Educacional S/A, co-fundador do Banco Pactual e sócio fundador do Instituto Millenium) tem por finalidade agilizar os processos de privatizações das riquezas naturais (água, petróleo, minérios), de empresas públicas (Banco do Brasil, Caixa Econômica Federal, 
Petrobras, Eletrobras) e dos regimes previdenciários estatais. Também compete a Guedes aprofundar a reforma administrativa do Estado, sob a égide do neoliberalismo ultraliberal (Estado Mínimo) e priorizar parcerias comerciais nem sempre pautadas em "vantagens comparativas" para o País, como já tem transparecido nas relações subalternas do novo governo com emissários e chefes de Estado e de Governo dos Estados Unidos da América e Israel, que também impuseram ao Brasil a não adesão ao Pacto Global de Migração da ONU e a instalação de bases militares americanas no país.

No tocante à educação, a CNTE não abrirá mão de lutar por mais investimentos públicos, para garantir oferta pública, universal, gratuita, democrática, laica e de qualidade social nos níveis básico e superior. E, para tanto, é fundamental e urgente a revogação da Emenda Constitucional 95!

Não aceitaremos a política de militarização das escolas públicas, que ganhou status de subsecretaria na estrutura do Ministério da Educação, através do Decreto 9.465, de 02.01.19. Essa medida afronta preceitos constitucionais e em razão disso a questionaremos judicialmente. Também será objeto de denúncia judicial as agressões verbais do sr. Marcus Vinícius Rodrigues (Presidente do Inep/MEC) contra os/as professores/as brasileiros/as; e repudiamos veementemente os recentes pronunciamentos preconceituosos e de afronta ao estado laico da sra. Damares Alves, Ministra dos Direitos Humanos, da Família e dos Direitos da Mulher. Como almejar uma sociedade pacífica com gestores públicos difamando e agredindo professores, estimulando o machismo, a homofobia, a violência policial contra grupos sociais, entre outras práticas condenáveis até mesmo pela legislação penal?!

A valorização dos profissionais da educação pública, através de ingresso na carreira por concurso público, com instituição de piso salarial profissional nacional previsto no Art. 206, VIII da CF/1988, com formação inicial e continuada garantida pelo Poder Público em instituições públicas, com jornada de trabalho e planos de carreira compatíveis com o exercício laboral e o reconhecimento social da profissão, com ampla gestão democrática nas escolas e nos sistemas de ensino serão pautas permanentes da CNTE. Da mesma forma, constarão na lista de reivindicações dos/as trabalhadores/as em educação, em conjunto com a sociedade, a aprovação do Fundeb Permanente, com mais recursos da esfera federal e a consecução plena das metas e estratégias do Plano Nacional de Educação, com destaque para as regulamentações do Custo Aluno Qualidade e do Sistema Nacional de Educação.

O discurso falacioso de combate ao socialismo, à ideologia de gênero e à doutrinação marxista escolar, por parte dos/as professores/as, será combatido diuturnamente por nossa Entidade, pois além de descabido, tem por objetivo criar um inimigo comum para a sociedade (o/a professor/a!!!), desviando a atenção da população para o que de fato interessa: o desmonte das políticas públicas essenciais que certamente afetará a qualidade de vida do povo brasileiro! 
No dia 11 de dezembro de 2018, o movimento educacional conseguiu importante vitória no Parlamento, derrotando a proposta de Lei da Mordaça (intitulada Escola sem Partido), apoiada pelo atual governo, que previa instituir mecanismos de censura nas escolas com punições aos educadores.

A educação e seus trabalhadores são vanguarda na luta social brasileira, e assim continuaremos!

Brasília, 9 de janeiro de 2019 Diretoria da CNTE 